\title{
Sales capability creation during new product development - early involvement of sales
}

\author{
Petteri Annunen, Erno Mustonen, Fanne Harkonen and Harri Haapasalo \\ University of Oulu, Oulu, Finland
}

\begin{abstract}
Purpose - This study aims to focus on creating sales capability as part of new product development (NPD). The aim is to define generic requirements for building sales capability as a part of NPD and to propose a necessary process by defining key activities for sales readiness.

Design/methodology/approach - An inductive and qualitative research method was used to construct a sales capability creation process based on a current state analysis in seven companies.

Findings - The results indicate that the status of companies' sales-related planning varies during the NPD, and the related activities are not systematically managed. Considering sales early is necessary to enable a smooth and cost-efficient start of sales, and to avoid unnecessary delays and problems in other functions. At the same time, the companies recognise the need for improvement.

Originality/value - This paper presents a potential process including systematic activities for creating sales capability in conjunction with product development, which is novel to the literature. The proposed process is applicable in aligning industrial company needs.
\end{abstract}

Keywords New product development, Sales, NPD process, SaCC, Sales capability, Sales capability creation

Paper type Research paper

\section{Introduction}

Time-to-market is a key requirement for the success of new product development (NPD) projects (Chen et al., 2005; Alfonso et al., 2008; Zidane et al., 2018). However, time-tomarket is deficient as it only measures the lead time of an NPD project, when also other capabilities (manufacturing, packaging, invoicing, etc.) need to also be considered. Traditionally customer needs and demand initiate the NPD process, and also company's internal strategy, technologies and capabilities are increasingly important drivers (Harmancioglu et al., 2007; Majava et al., 2013), especially product development capabilities (Tatikonda and Montoya-Weiss, 2001; Yan et al., 2021). Successful NPD needs to consider twofold information and knowledge flows, from later life-cycle phases to the fuzzy front end (Design for Excellence) (Lehto et al., 2011) and also from NPD to later life-cycle phases (Capability Creation) (Tolonen et al., 2017).

NPD process has a key role in the entire product lifecycle (Lahtinen et al., 2019). Logically, all the decisions made during NPD affect the costs and quality of the product and the processes in later maintenance and ramp-down phases (Ulrich and Eppinger, 2008), regardless of whether those are decisions within the NPD process or not. Most of the company's key processes need to be built and aligned with the product already during the NPD (Filippini et al., 2004), involving crossorganisational functions and their capabilities to improve NPD performance (Kang et al., 2020).

The current issue and full text archive of this journal is available on Emerald Insight at: https://www.emerald.com/insight/0885-8624.htm

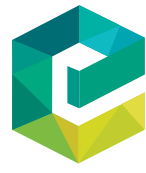

Journal of Business \& Industrial Marketing 36/13 (2021) 263-273

Emerald Publishing Limited [ISSN 0885-8624] [DOI 10.1108/JBIM-06-2020-0274]
Systematic and early inclusion of cross-organisational functions, particularly sales, in terms of considering capabilities is deficiently addressed in the literature and lacks insights. Literature on product market launch (Kuester et al., 2012) and generally marketing literature (Tynan and McKechnie, 2010) focus on the customer perspective in introducing new products, and do not discuss offering full solutions for internal sales activities. In addition to NPD, a seamless sales process is a vital part of the business. When companies introduce new products, sales capability is critical to be planned and created alongside the NPD to enable as efficient sales as possible (Jobber and Lancaster, 2009). This importance has been well-recognised, but possible sales planning-related processes as part of the NPD have not been widely discussed in the previous literature (Malshe and Biemans, 2014). Sales-related planning should be a part of a well-organised NPD, and it should also consider the requirements of the company's sales process. NPD process and the sales process need to be well-aligned to achieve the maximum benefits (Barczak and Kahn, 2012).

Capability creation-related processes form a part of a systematically managed NPD (Isoherranen and Majava, 2018). In the capability creation (CC) concept the planning and building of all the key capabilities related to the key processes

(c) Petteri Annunen, Erno Mustonen, Janne Harkonen and Harri Haapasalo. Published by Emerald Publishing Limited. This article is published under the Creative Commons Attribution (CC BY 4.0) licence. Anyone may reproduce, distribute, translate and create derivative works of this article (for both commercial and non-commercial purposes), subject to full attribution to the original publication and authors. The full terms of this licence may be seen at http://creativecommons.org/licences/by/4.0/legalcode

Received 10 June 2020

Revised 13 October 2020

11 June 2021

27 August 2021

Accepted 21 September 2021 
are started during the early phase of the product development to ensure efficient project implementation and successful product manufacturing, sales and maintenance right from the beginning (Tolonen et al., 2017). However, based on earlier related research by Tolonen et al. (2017) and Verrollot et al. (2017), supply chain capability creation (SCCC) process and supply capability creation (SCC), such CC processes have not yet been recognised in the industry as a systematic way to build capabilities during NPD. The same applies to sales capability creation (SaCC), including the capabilities of both, the sales organisation (Guenzi et al., 2016) and the entire company supporting sales. Therefore, the purpose of this study is to provide insights on the systematic and specific creation of sales capabilities as a part of or parallel to NPD and to consider a related process to effectively involve relevant customer knowledge and the needs of sales. The objectives of the study are organised through the following research questions (RQs):

$R Q 1$. What are the cornerstones to support creating salesrelated capabilities during the NPD?

RQ2. What is the current state of creating sales-related capabilities during the NPD phase?

\section{RQ3. How can systematic $\mathrm{SaCC}$ be described as a process?}

We initiate our qualitative study by a literature review on the sales process, NPD process, their key connections, and the NPD-related organisational set-up to provide foundations (RQ1) for our empirical study. After the literature review, we generated a set up for semi-structured interviews (Bryman and Bell, 2011) in our case companies to outline their current activities of creating sales-related capabilities during the NPD phase, and to clarify how their NPD management teams and roles are organised $(R Q 2)$. Finally, the paper describes how the sales capabilities are built during the NPD processes. Insights are provided to the current practices, and a SaCC process description is proposed and validated, including the key activities $(R Q 3)$.

\section{Literature review}

\subsection{Sales process and new product development process}

Simplest way to define selling is by describing it as the function that makes the sale. It includes complex processes, principles, techniques and tasks (Jobber and Lancaster, 2009). Sales process is a process involving a series of defined steps that enable sales force to work systematically and efficiently: increase margins and make more sales. Sales process is most commonly defined in 5-8 steps (Moncrief and Marshall, 2005; Jobber and Lancaster, 2009). When using the traditional seven steps of selling, the following are included: prospecting, preapproach, approach, presentation, overcome objections, close and follow-up (Moncrief and Marshall, 2005).

Product development capabilities generate the market success (Tatikonda and Montoya-Weiss, 2001) and NPD is as good as the NPD process is (Harmancioglu et al., 2007). NPD process aims to refine product ideas up to the product launch, including product design and operations planning (Harmancioglu et al., 2007). NPD process has several definitions, but one of the well-known is the stage-gate system by Cooper (2011) having business management approach in his model. In the stage-gate system, the key stages are idea generation, scoping, building a business case, development, testing and validation and launch. Another common, content driven method, is by Ulrich and Eppinger (2008), consisting of planning, concept development, system-level design, detail design, testing and refinement and production ramp-up stages.

Well-defined key performance indicators (KPIs) and predefined targets are important to evaluate, if the product is ready to proceed to the next steps (Ulrich and Eppinger, 2008; Cooper, 2011; Barczak and Kahn, 2012). Without gates, the NPD follow-up and efficiency of the stages cannot be ensured (Kess and Haapasalo, 2002). One of the best practices relating to company processes is a common NPD process that overarches across the company (Haapasalo and Kess, 2002). Similarly, one of the best practices relating to commercialisation is the cross-functional teams making the decisions concerning the key functions, including sales (Barczak and Kahn, 2012). Product development team is, hence, an integral part of any NPD project. The presence of sales, design and manufacturing in the project team are essential (Ulrich and Eppinger, 2008).

\subsection{New product development and sales process co- operation}

Companies focus on improving their NPD processes as an answer to turbulent markets, to gain the benefits of efficient time-to-market (Majava et al., 2013). The NPD process must support activities that aim towards the commercialisation of new sales items (Carrillo and Franza, 2006; Lehto et al., 2011). However, time-to-market requirements must also be in line with the capabilities of the company to support long-term company success (Ellwood et al., 2017). In a systematic NPD process, there must be requirements related to sales (Lehto et al., 2011). Cooper's (2011) stage-gate model includes general requirements, such as preliminary market assessment in the scoping phase and competitive analysis in the stage of business case building. In the following gate (go to development), for example, preliminary sales plans are reviewed and approved, and product development can start. In the testing and validation stage, trials such as trial sell are done. In the last product development-related gate, the product is ready to launch with full commercialisation including market launch. Voice of the customer needs to be involved throughout the entire NPD project (Cooper, 2019).

Sales has a role in providing field-level intelligence to the NPD process (Morgan et al., 2019; Sundquist and Melander, 2021). Sales help research and development (R\&D) to connect with key customers and supports in finding the best trial partners. Some companies have specific customer management organisation to analyse and provide complex customer knowledge for NPD (Kinnunen et al., 2014). Sales also introduce the new products to the customers (Malshe and Biemans, 2014). Cooperation between the NPD and the sales has a significant positive effect on the overall project performance (Kang et al., 2020). It is studied that the cooperation of $\mathrm{R} \& \mathrm{D}$ and sales in the concept and product development stages is critical for the product success (Ernst et al., 2010). Proactive use of the salesforce is an integral part of the opportunity identification process. It also enables the 
integration of customer's voices into product development and increases customer satisfaction and operating profits (Gordon et al., 1997). Sufficient sales force resource allocation to NPD projects correlates critically with total NPD performance (Cooper et al., 2004a). Similarly, well-executed sales-related tasks (e.g. trial selling) heavily affect the total performance of the company (Cooper et al., 2004b). Nevertheless, systematic studies of sales contribution during all NPD stages are scarce (Malshe and Biemans, 2014; La Rocca et al., 2016):

Literature highlight: It is one-way information and knowledge flow to provide sales process's needs and requirements to NPD, but it also requires the flow towards the opposite direction to generate responses (capabilities) for sales, maybe even by a different process.

\subsection{Capability creation during new product development}

Supply chain integration to NPD has an impact on performance (Caniato and Größler, 2015). Tolonen et al. (2017) defined SCCC process-related pre-requirements based on a model used in the electronics industry. Verrollot et al. (2017) further defined SCC process-related key activities based on six different companies, representing several industries. SCC can be considered as a part of the SCCC in a similar way as production and logistics capability creation (Tolonen et al., 2017). Similarly, previous studies have suggested that creating capabilities in product development for customer care are essential for success in the maintenance phase (Isoherranen and Majava, 2018).

Earlier studies have found that sales and supply chain alignment should be started as early as possible in the NPD process (Van Hoek and Chapman, 2007). Customer inputs have a vital role in the prototyping of the product (Tih et al., 2016) and should be part of the NPD process as early as possible (Cooper, 2019.) Sales capabilities have a positive relationship with the performance of the company (Guenzi et al., 2016) and the market share (Brahmane, 2014). However, the process of creating sales capabilities during the NPD has not been defined in the earlier literature. The process to describe the activities should be in line with previous research alongside the SCCC process during the NPD process. Overall, well-defined and controlled key processes are generic requirements for SaCC. In the product process, a working NPD process is needed so that several business processes can be incorporated. Key stages of the process, including the key gates, is essential (Ulrich and Eppinger, 2008). One generic requirement for $\mathrm{SaCC}$ is the support of the structures of the organisation and the NPD team, which need to support the SaCC process implementation (Tolonen et al., 2017):

Literature highlight: Previous research recognises the benefits of considering the sales capabilities in NPD, but it does not explain how to build sales readiness and capabilities as a part of NPD process.

\subsection{Synthesis}

Company key processes need to be defined to support the optimum way of working and to achieve time-to-market-, quality- and cost-related targets (Cooper, 2011). NPD process and sales process are two of these key processes. The organisation needs to support these processes: cross-functional teams from all parts of the organisation need to support the NPD process and the sales-related planning during the NPD (Barczak and Kahn, 2012). It can be said that cooperation between sales and NPD is essential for time-to-market, costs and quality. Figure 1 illustrates the interrelation and integration between the NPD process and sales process as can be synthesised based on the literature.

Needed tasks for sales-related planning and SaCC must be clearly defined and agreed in the beginning of the NPD project, for each of the project phases. Stage-gate model or similar milestone model with detailed tasks will support defining and agreeing the tasks (Ulrich and Eppinger, 2008). As detailed activities, planning of the sales objectives, the product concept and the sales strategy are critical in the sales planning. A preliminary market launch plan and preparation of the salesforce and distribution, customer service and support and pricing need to be defined before the trial sell. After implementing the market launch plan, it is essential to measure, control and adjust the plan according to customer needs and markets (Cooper, 2011). In any case, there must be a balance between the speed of time-to-market and the capabilities and processes of the company to avoid negative consequences in the longer time frame (Ellwood et al., 2017; Zidane et al., 2018):

Figure 1 Sales capability creation process aligned with NPD process, interacting with sales process

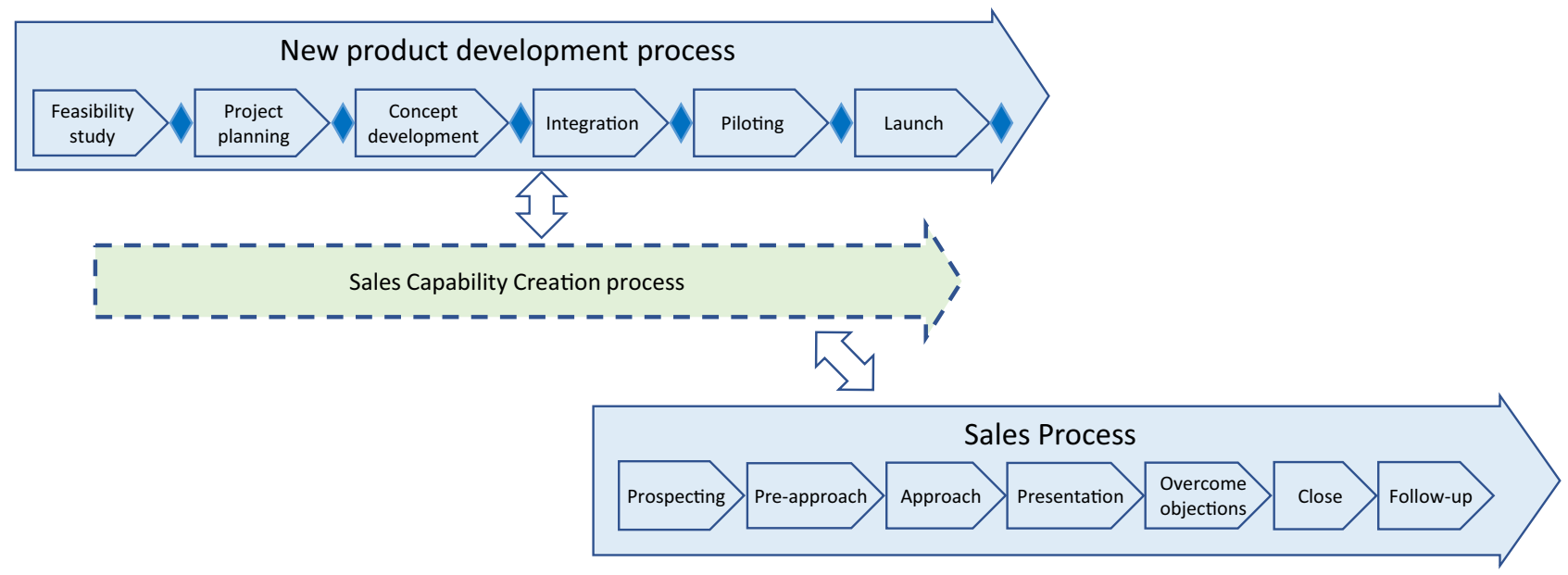


Literature highlight: NPD process, sales process and organisational structure are required to support efficient and systematic building of the sales-related capabilities.

\section{Research process and method}

An inductive and qualitative research method was applied to study the current NPD, sales and SaCC practices of seven companies and to construct a SaCC process model. The research process is illustrated in Figure 2.

The literature review consisted of analysing the current literature on the sales process, NPD process and their interaction. The literature review also assisted in creating the interview questionnaire to support the empirical investigation. The empirical data were collected via semi-structured interviews (Bryman and Bell, 2011) in seven companies. Variable size companies with expectedly different process maturities were selected based on their motivation to develop their SaCC during NPD. This selection was intentional to reveal a variety of challenges. All the selected companies act in high-tech business, where the importance of creating sales capability already during the NPD is critical in the light of timeto-market requirements (Homburg et al., 2017; Veldhuizen et al., 2006). One to four key persons from each company were interviewed (Table 1). The interviewees were selected with snowball sampling (Bryman and Bell, 2011) within the companies, to cover the key persons having needed knowledge related to SaCC. Basic general questions were first asked to understand the companies' sales and NPD processes, the general questions also included the structure and roles of the NPD project management team. More detailed questions that followed included, asking about the sales requirements in NPD and the process of considering sales requirements in NPD. NPD process inputs to the sales process and other requirements in NPD were also queried. The interview sessions were carried out face-to-face, except in two companies, who opted for virtual meetings. Each interview session lasted $1-2 \mathrm{~h}$.

All the information from interviews and the literature review were analysed by the means of content analysis, which usually consists of data collection, coding, analysis of content and interpretation of the results (Duriau et al., 2007). The transcripts of the interviews were carefully read though to create an initial understanding of the data. Notes of the readings were listed to outline all the insights. The transcripts were read through three times to extract all the interviewees' comments relevant to the sales capabilities. SaCC activities were identified from both the interview data and the literature.

The SaCC-related activities were identified based on the five categories by Vorhies and Morgan (2005), namely, giving salespeople the training they need to be effective, sales management planning and control systems, salespeople selling skills, sales management skills and providing of effective sales

Figure 2 The research process

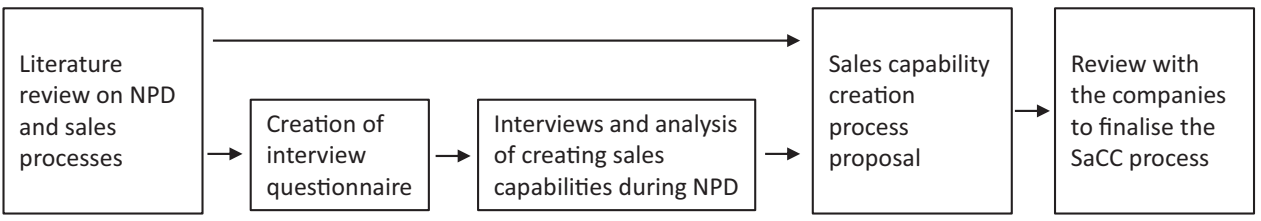

Table 1 Description of the companies and the interviewees

\begin{tabular}{llll}
\hline Company & Size* & Type of business & Roles of the interviewees \\
\hline A & Small & Designing and manufacturing of electronic components & $\begin{array}{l}\text { Sales manager } \\
\text { Head of product creation }\end{array}$ \\
& & & Field application engineer \\
B & Medium & Designing and manufacturing of customised electronic products & Senior application specialist \\
C & Large & Designing and manufacturing of mechanical power transmission equipment & Vice president of R\&D \\
& & & Key account manager \\
D & Small & Designing and manufacturing of electrical devices and solutions for medical operators & Head of product lifecycle management \\
& Large & Manufacturing of high-end medical equipment & R\&D director \\
E & & & Product manager \\
& & & Area export manager \\
& Large & Leading provider of heavy equipment in its industry & After sales director \\
F & & & Programme manager \\
& & & Director, Business processes and IT \\
& & & Sales Support and Process Manager \\
& Large & Component manufacturer of electromagnetic products & Vice President, Technology \\
G & & & Manager of Engineering
\end{tabular}

Note: *According to the definition of the European Commission 
support to the sales force. Only the product-related skills of these five categories were used and the two skills-related capabilities were scoped out. The two were scoped out as they were seen as human resource management-related issues. Research team also included sales capability-related activities as one additional category.

After identification of the activities, they were transformed into codes. The codes from the interviews and the current literature were categorised according to the six stage-gate process stages, namely, feasibility study, project planning, concept development, integration, piloting and launch. The obvious ones were placed to correct stages (0-5) of the NPD process presented by Cooper (2011), but the remaining codes were left over for further discussion to ensure correct placement. The categorisation of information was discussed within the research team to ensure common understanding and interpretation.

In the next phase, all the codes were connected according to similarities. Duplicate codes were eliminated and partially overlapping codes were either integrated or divided into separate codes. Then, the final codes were formulated as SaCC process activities. Initial descriptive names were given for each activity. The activities possible to be generalised were finetuned and summarised and final definitions for the activities were given.

The SaCC process definition was created based on the codes from the interviews and the coded findings from the earlier literature. Two workshops were held within the research team to organise all the remaining unclear activities to correct stages and finetune the process, after which the initial SaCC process was proposed. The proposed process was presented to the participating companies and feedback was collected and analysed to ensure the validity and to finally adjust the process accordingly.

The studied companies consist of companies of various sizes and high-tech industries. Company $\mathrm{A}$ designs and manufactures electronic products and has its markets in different industries. The company is growing fast, and its internal processes and their role are being increasingly emphasised. The company has sales offices and a presence in all the key continents. Company $\mathrm{B}$ designs and manufactures customised electronic products for customer applications in several industries and research areas. The company has research, production and sales under the same roof and several distributors around the world. Company C designs and manufactures special equipment and offers related services. The company is smaller than many of its competitors, and therefore works closely with its customers to meet their specific needs. The company provides extremely customised products with a flexible and fast product development process as its main competitive advantage. Company D is a small company with tens of distributors for its product in markets around the world. The company sells electrical devices and solutions for several types of operators in the industry area. Company $\mathrm{E}$ manufactures high-end equipment for one business area. The company has customers in more than 100 countries, different customer types ranging from private workers to bigger companies. Majority of the sales is conducted via local distributor networks with hundreds of distributors. Company $\mathrm{F}$ is the world's leading provider of products and systems in its own industry, with a big variation in its customers. Big part of the company's revenue comes from service and maintenance, the company having hundreds of service points in tens of countries. Company $\mathrm{G}$ is specialised in the production of hightech products to its customers' solutions. The company has customers in three different business areas and sales representatives in all continents.

\section{Results}

\subsection{Current state of new product development and sales} in the analysed companies

4.1.1 New product development and sales processes

NPD process is one of the backbones in all the analysed companies. Key tasks for each project phase, including KPIs, are defined and seen as essential. Documentation practices, communication between the participating organisations and ensuring the co-operation throughout the project form the basis for good NPD processes. All the companies have working NPD process descriptions in place. Also, the companies have some form of evolution of a stage-gate model in use as part of their NPD processes. The number of the stages varies from three to six, depending on the company. The stages conform substantially with the NPD process descriptions found in the literature, as described by an interviewee:

"IIn company A] we have these 6 stages: discovery \& planning, opportunity validation, feasibility study, product creation, testing $\mathcal{E}$ validation and launch. We might have some limitations or additional requirements for basic NPD process from framework agreement with customers."

As an example of more detailed findings relating to the NPD processes, Company $\mathrm{D}$ has a well-defined stage-gate process in place, but as a smaller company, it is yet to include clear responsibilities and ownerships. Company $\mathrm{C}$ agrees about some gaps in its NPD process, for example, that key suppliers could be more connected in the company's NPD projects. Company B, on the other hand, does not have sales or sourcing teams involved in the NPD process-related work. It has partially caused a situation where, for example, product-related specifications and costs are not so well in control due to the lack of price, demand and delivery volume information in NPD.

Importance of an efficient sales process is well-recognised in all the companies. The sales process itself is mainly welldefined and includes good elements that cover sales plans and measurements/control of the sales with relevant KPIs. Roles and, for example, sales channels are included, to cover technical restrictions in certain market areas or customers as the necessary background information sales. The sales processes of six out of seven companies have the same basic elements in place as defined in the literature for the traditional type of sales process.

These six companies have from three to six key phases in place in their sales process, including some specific attributes. Interviewee of the Company B described these attributes as:

"In our sales process a software-based control ensures that sales personnel follow the protocol. In addition to that, the sales personnel also work on understanding the customer needs and try to support the NPD process at the early stage."

Company A has a relatively strong sales process compared to the size of the company's business and has divided it into five sub-processes. Company C, on the other hand, is working closely with each customer, who are original equipment 
manufacturers in the industry. The company has detailed and clearly defined sales process because of the importance of the customer relationship in the joint venture type of development projects. Contrary to the other six companies, Company E does not have a defined sales process in use at all. It was a significant finding because the company sells its products to more than 100 countries and the end-users vary a lot. Company E representative clarified this as:

\footnotetext{
"We do not currently have a structured sales process or sub-processes defined, at least in the European market area. The sales process is flexible and adapted to customers' needs, many different paths can lead into the same result."
}

\subsubsection{Structure of the new product development project management teams}

According to the interviewees, the structure of the organisation and the alignment of different key units affect the implementation of new processes in the companies. Organisational structure also supports NPD work and efficient start of the sales. Agreeing a detailed team and responsibilities related to sales already in NPD supports in managing the salesrelated activities throughout the entire NPD. Setting up info channels and communication/reporting with the whole NPD is seen as important. It is also essential that the organisational structure supports the NPD with all the sales scenarios, both in trials and after the market launch. NPD project management team is the key in building the aforementioned capabilities.

The interviewed companies have some variations in the structure of the NPD project management team. Most of them have a defined, wide representation of all key organisations in NPD projects, but some exceptions also exist. Size of the NPD project management team varies from four to eight representatives, based on the company's organisational structure and size. One interviewee defined the company's sales representation in NPD management as follows:

"IIn company D] we have sales well presented in the NPD management team and have a good interworking with RED, supporting consistent and efficient bidirectional information flow."

Some specific differences exist between the companies. Company A has project-based, defined key roles for participating in the management of NPD projects, including sales representation because of variating projects. Because Company $\mathrm{B}$ is relatively small, it has its NPD projects managed by the company's management team. In Company $\mathrm{E}$, sales representatives are involved only in the management of the biggest NPD projects, and in Company G, roles have been agreed a bit differently: the product manager is taking customer feedback, and lead engineers to take care that customer requirements are included to development work. However, there is no representation of sales in the NPD project management team in Company G. On the other end of the scale, Company $\mathrm{F}$ is a large global company, and it has built both the steering team and the technical team in its NPD project management.

\subsubsection{Relationship of the key processes and roles}

NPD and sales have their own roles in the companies' business. Compared to process activities and roles defined in the literature, the companies had also some differences and interesting details in their ways of working. As an example, Company $\mathrm{A}$ is using two different databases for sales and product development personnel, which causes problems in information sharing. Additionally, the sales personnel are not involved in the company's lessons learned practices, which makes the gap in information sharing even bigger. In Company $\mathrm{B}$, the continuous co-operation practices between NPD and sales are admitted as weak.

For example, Company D has good interworking between the sales and product development processes: bidirectional information flow between the product development and sales process, and structured requirement gathering activities are well-defined. Sales readiness is also built during the NPD process. An interviewee from company $\mathrm{D}$ describes the tasks by sales as:

"Sales provide important customer and market analysis information for the product requirements and provides also additional information such as product feedback and possible improvement ideas to product development. The product development provides feedback, product-related support and tools for the sales organisation."

In Company E, NPD projects currently work closer to sales than in the past, together they innovate and gain feedback from each other to match commercial requirements with the technical ones. The company also has a four-phase process for considering and finally approving sales requirements in NPD. To the other direction, NPD key inputs to sales are technical information packages, product training sessions to sales and distributors. After product launch, the company's website and brochures are the key info channel from NPD towards sales and at the same time directly to end customers.

Company $\mathrm{F}$ has a good connection between the sales and NPD processes, which is created also with several tools and systems. One interviewee of Company F defined the current practice as follows:

"To ensure fluent communication, we have created a tool that supports the alignment of the sales process and the NPD process. It works as a sort of checklist. In this tool, for every NPD phase there is an equivalent phase for the sales process, including defined actions."

As part of NPD projects, Company $\mathrm{F}$ has regular sales and operations planning meetings, where the issues between sales, production and delivery capability are systematically processed.

\subsubsection{Sales capability creation}

SaCC-related activities are currently carried out in the interviewed companies as part of sales process, NPD process or some other process or not done at all. The need for a systematic process in creating sales capabilities during NPD was, however, recognised. As an example, the interviewee of Company $\mathrm{A}$ explained the current sales capability considerations:

"Currently sales capability creation can be seen to take place in two phases in the NPD process: when updating the NPD possibility and limitation checklist and when gathering lessons learned from the NPD process."

Based on the interviews, there are some specific findings related to SaCC-related tasks. A key problem in Company B's SaCC is that some of the capability creation-related critical connections from $R \& D$ to sales, such as training for sales organisation on the technicality of the products, have not been built. Company $\mathrm{C}$ has a detailed sales process description including also the most important SaCC aspects. This is mainly because of the close co-operation with the customers in each project. Company $\mathrm{C}$ representative described the situation as:

"Sales capabilities are built as a project by sales manager in close co-operation with $R \mathcal{E} D$ and product line management. Sales manager is also communicating with the customer." 
Company $\mathrm{F}$ has a checklist type of description for ensuring the building of sales-related capabilities during NPD. In addition, a systematic SaCC process development is in planning. The company is starting a pilot project that integrates different business processes through a product data management system.

As summary, the companies have some good practices in place for systematic SaCC, starting with market analysis, setting specific cost and price targets and estimated delivery volumes. Some companies are putting the product information to an automated system, to give feedback about the product to $\mathrm{R} \& \mathrm{D}$. Some are also providing sales training, as well as preparing the sales materials and documentation. Several practices are in place, but differently, in different companies, some having many aspects in use, some less.

\subsubsection{Current state synthesis}

The basics of the key processes are in place in the studied companies. NPD processes and sales processes generally work. However, key elements are missing in organisational cooperation, relationships among the processes and some process parts missing. Some companies have noticed the need for the missing elements and realised their significance.

The definition of SaCC process is missing in almost all the analysed companies. Proper planning of the sales-related tasks and key activities during each stage of the NPD process would support building the sales capabilities during the product development, and at the same time in giving customer feedback to product development through organised sales functions and processes.

Certain tasks that relate to SaCC are done, and communication between sales and R\&D is generally in a good level. However, systematic management of creating sales capability is weak. Before the product development starts, it is important to define, when and how the responsibilities between sales and other organisations will be agreed, when a sales plan is needed and how sales-related information and trials are managed from the sales viewpoint:

Empirical finding: The results indicate that NPD process, sales process and NPD organisational structure can support the creation of the SaCC process. However, the status of sales-related planning during NPD varies in companies, and the related activities are not systematically managed. The companies recognise the need for related improvement (Figure 3).

\subsection{Sales capability creation process}

The proposed SaCC process is bases on the literature review and the empirical analysis. The developed SaCC process also applies the NPD process along Cooper's (2011) stage-gate model. The relevant pre-requisites to implement the SaCC process include well-applied NPD and sales processes, and an organised NPD project management team to support the work and to ensure the stage results in each gate review. With these pre-requisites, the proposed SaCC process can be applied in the operative management of the companies.

Figure 4 presents the process landscape, the SaCC process aligned with the NPD process and with constant interaction with the sales process. Sales start to engage with the NPD process through the SaCC process during the feasibility study phase and continue the interaction with the entire NPD process up to the launch stage, to have the sales capability in place before the sales process.

Figure 5 illustrates the developed SaCC process and the related activities owned by the NPD management team in each NPD stage. All the stages 0-5 are the same as in Cooper (2011) has in his NPD process. In the developed model, each stage has a gate G0-G5 for SaCC. In each of these stages, the activities listed in Figure 5 are finalised and the status of the activities are checked. All the activities referring to literature are marked in Figure 5 to separate the empirically based on those activities presented in the literature. The activities have been supplemented based on the interview data, to finalise the SaCC process.

In the "Sales targets" (Stage 0), the basic planning of the sales objectives and strategy are addressed before Gate 0: "Initial communication within the company." In the "Initial sales plan" (Stage 1), the work proceeds to Gate 1: "First version of the sales enabling plan." The "Operative sales plan" (Stage 2) includes establishing a team and agreeing responsibilities to manage the sales of the product, setting up the information channels and communication/reporting with the entire NPD team and other necessary parties. Basic sales data are also defined in the systems for the first time, and sales channels are planned. KPIs related to sales are needed before proceeding to the following stage. "Sales enabling plan" is finally ready in Gate 2 .

In the "Detailed sales plan" (Stage 3), details related to sales are defined and also sales are planned for all delivery models. Order

Figure 3 According to empirical findings, SaCC process should locate beside NPD process in new product development

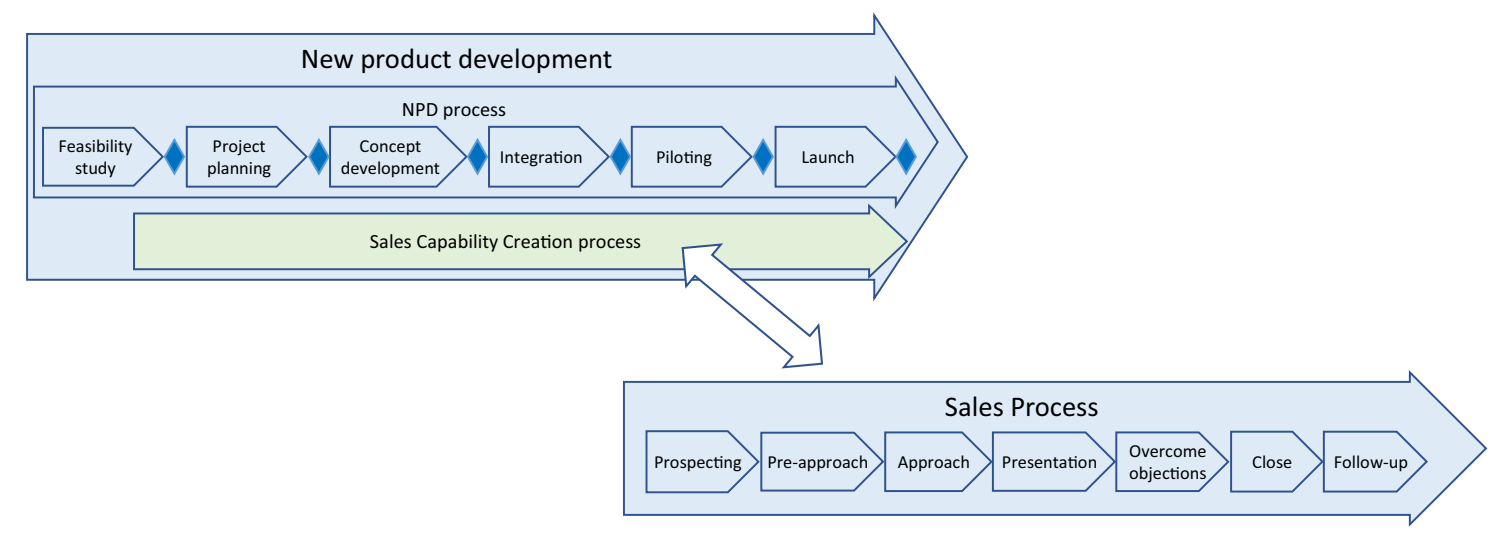


Figure 4 The sales capability creation process aligned with the NPD process. The SaCC process gives inputs to the sales process and the sales process provides requirements and communicates needs to the NPD process

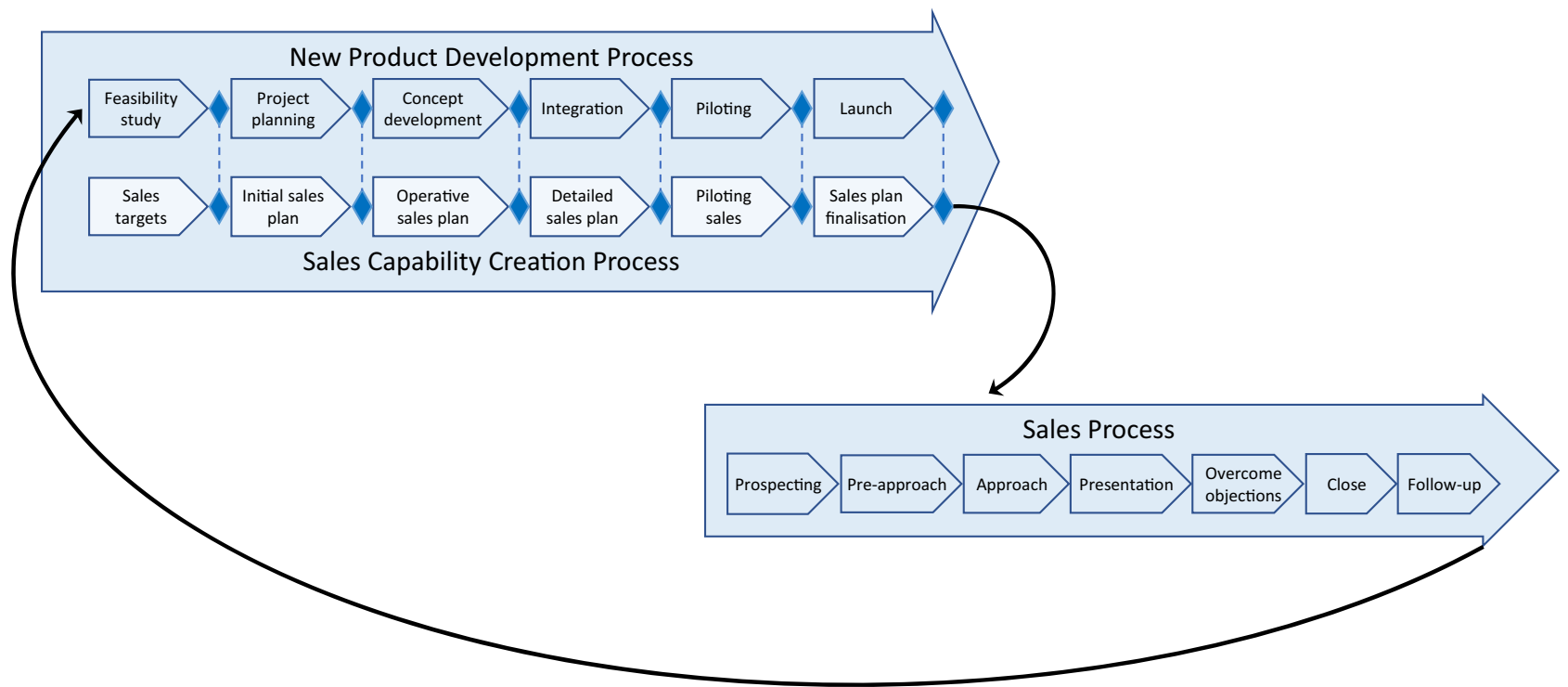

Figure 5 Key activities in each stage of the sales capability creation process

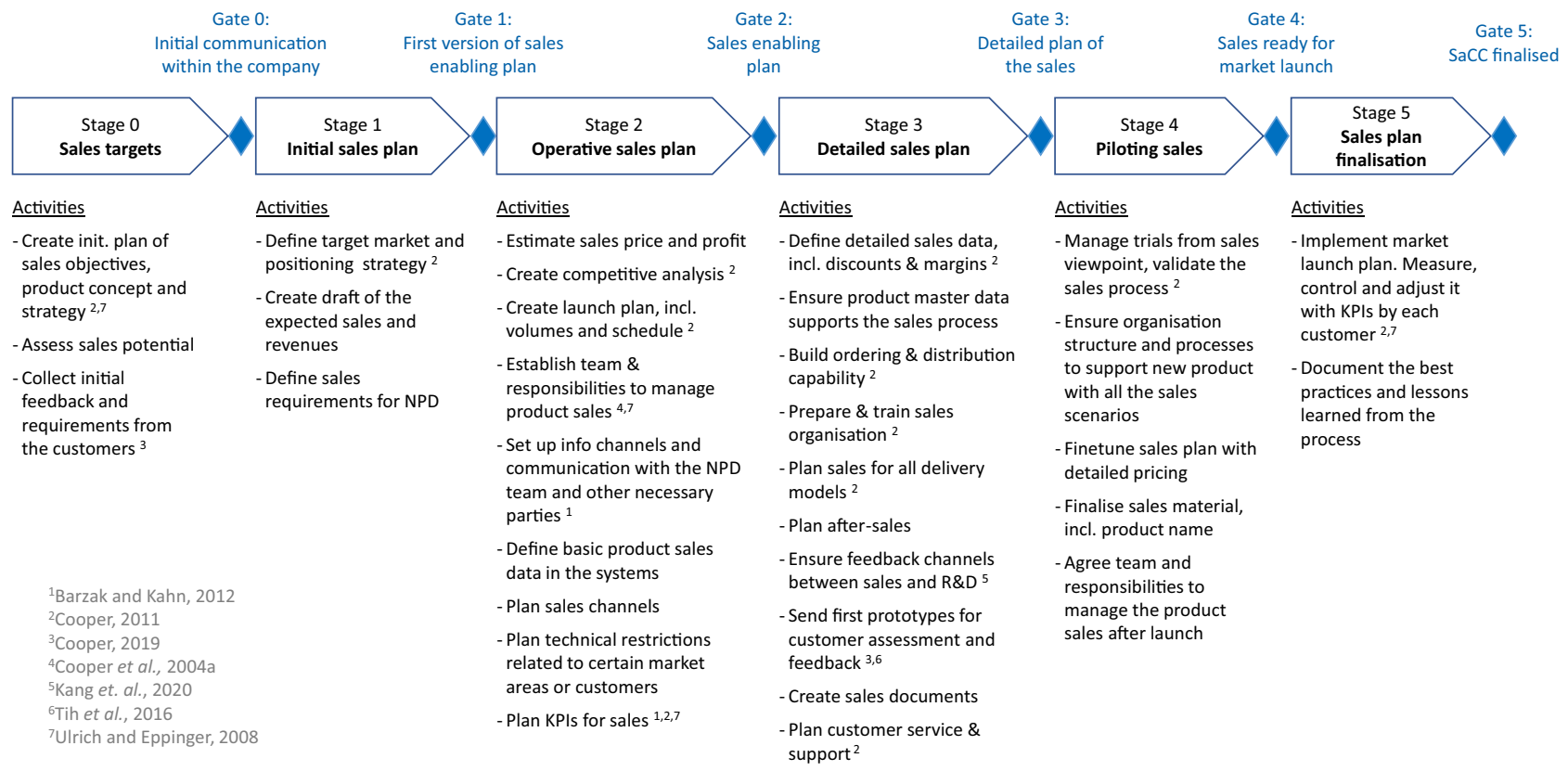

handling capability is built simultaneously, and product master data need to already support the sales process. The sales organisation is prepared to take orders, and feedback channels between sales and product development are ensured. Customer support management is also planned, and the first sales documentation is prepared. In Gate 3, a "Detailed sales plan" is ready.

In the "Piloting sales" (Stage 4), the sales process is validated with necessary trials. The sales plan is also fine-tuned, and sales materials are finalised. After this, the sales organisation is prepared to support new product sales with all sales scenarios, and the responsibilities to manage the sales after product launch are agreed. In Gate 4, the "Sales is ready for market launch." In the "Sales plan finalisation" (Stage 5), market launch is implemented according to the plan, and as being measured, controlled and adjusted with the KPIs, the best practices and lessons learned are important to be documented before the systematic Gate 5, "SaCC finalisation" (post-launch review).

Based on the validation feedback in the participated companies the proposed process could be feasible in the studied companies. SaCC-related activities need to be aligned with the entire NPD process and be included as part of the daily way of working. It is necessary to understand that the defined 
SaCC process may need to be modified based on company size, the company's NPD process, and the type of products to be developed. In a large company, all the key activities are valid to be considered, but some may not be necessarily mandatory to be used in smaller companies. Each stage can be combined or divided according to the company's current set of NPD stages to ensure the usability of the process, which may be the case, especially in smaller companies. The entire process is aimed to be used with the initial product development, which means a product that goes through the whole NPD process. The process is modifiable also for smaller development projects.

\section{Discussion}

Efficient NPD and sales can be enabled by systematically managed processes. As a result of the systematics, in an ideal situation, the sales will be ready to sell the product according to its full potential immediately after the NPD phase. However, the related company-wide capabilities and their implementation have been described with deficient details in the previous literature. Hence, this study aims to describe how to manage SaCC during NPD, including the necessary prerequisites and the systematic management of the SaCC:

Research highlight: Sales capability refers to the organisation's preparedness to sell the product effectively over its entire lifecycle. The sales capability creation ( $\mathrm{SaCC}$ ) process aims at the systematic building of this capability right from the beginning of new product development. The process takes place parallel to the NPD process, and it is managed by the sales organisation.

The findings indicate that key cornerstones to support the creation of sales-related capabilities during the NPD include well-defined and inter-functional NPD and corresponding sales processes, which both have their roles and responsibilities clearly defined. One of the key cornerstones involves also the cross-functional organisational structure, where the NPD management team includes the sales representation.

The current state of creating sales-related capabilities during the NPD varies to a certain extent in the analysed companies. Some of the analysed companies have relatively good SaCC process elements in place, including checklists for each NPD process gate, and simultaneously have some rather light practices in place for systematic SaCC. As a starting point, one of the analysed companies was targeting to reach a fully working SaCC process, but none of the companies were yet to apply one. The significance of the potential SaCC process was well-understood by all.

The results indicate that $\mathrm{SaCC}$ could be handled systematically with a process proposed in this study. The process includes key activities for each stage of the NPD process before each of the defined gates. The described 32 activities in a total of six stages can be adjusted to be used based on stages in each of the applying companies. The larger the company, the more activities are necessary to be used when systematically creating sales capability.

The novel contribution of this study involves presenting a potential SaCC process to be used by companies to create sales-related capabilities during the NPD process. The other scientific implications of this study involve supplementing the current literature by describing the current status of SaCC during NPD in true companies. The introduced SaCC process provides a new contribution to Lehto et al. (2011), Malshe and Biemans (2014), La Rocca et al. (2016) and Cooper (2019) by filling the missing information of detailed activities during the sales-related planning in NPD. This study offers a solution on internal sales activities to support customer perspective in product market launch (Kuester et al., 2012) and generally marketing (Tynan and McKechnie, 2010). The process is also in line with Kess and Haapasalo (2002), Ulrich and Eppinger (2008) and Cooper (2011) and by following the stage-gate logic. However, this study brings new elements into the utilisation of the stage-gate model when building the salesrelated capabilities during NPD. The introduced SaCC process is an analogical continuum to the presented SCCC process (Tolonen et al., 2017) and SCC process (Verrollot et al., 2017). The process is also in line with related research (Barczak and Kahn, 2012; Isoherranen and Majava, 2018) highlighting the importance of creating maintenance phase capabilities already during NPD.

The managerial implications include providing an understanding on how practitioners can use the proposed SaCC process in managing their sales-related activities during product development, and to create the necessary capabilities. Companies can potentially decrease their timeto-market, improve quality and reduce unnecessary costs by applying the systematic method and by acknowledging the sales perspective early. NPD can also potentially be made more efficient by managing the described tasks during the NPD stages so that sales will be ready to its full potential at the point of product launch. The presented process can be tailored according to the needs of the company by adjusting the stages, activities and the detailed roles and responsibilities, to correspond with the company NPD process and the sub-processes.

The limitations of this study include the number of the analysed companies and the analysed industrial high-tech context. Also, the proposed SaCC process has not been applied in companies yet to its full extend and the resulting feedback of the real use remains limited. Nevertheless, the process and its applicability were initially validated together with the companies. Further validation would strengthen the results of the study. The other limitation involves the aspect that all the studied companies used the traditional types of sales and NPD processes, including stages and gates. In principle, the results of the study can be used also with other kinds of processes (e.g. dynamic sales processes or agile NPD processes), but may require further analysis. Hence, the results cannot be fully generalised to all industries and companies, but further studies are needed. However, the results of this study can be used as a reference point, when building a SaCC process in any industry, particularly because of the provided insights.

Future research is needed to cover more companies and includes different types of industries. The further focus on SaCC during NPD and the experiences of using the introduced process provides plenty of opportunities for valuable future research. For example, it could be beneficial to include marketing- and care-related literature and empirically study the benefits of combining marketing capability creation with the SaCC. Also, the capability creation area necessitates analysing which industries and process areas can be applied to give the most global and societal benefits. 


\section{References}

Alfonso, P., Nunes, M., Paisana, A. and Braga, A. (2008), "The influence of time-to-market and target costing in the new product development success", International fournal of Production Economics, Vol. 115 No. 2, pp. 559-568, doi: 10.1016/j.ijpe.2008.07.003.

Barczak, G. and Kahn, K.B. (2012), "Identifying new product development best practice", Business Horizons, Vol. 55 No. 3, pp. 293-305, doi: 10.1016/j.bushor.2012.01.006.

Brahmane, J. (2014), "An empirical study on sales capability and marketing implementation capability of SMEs in India and their impact on market share", IOSR fournal of Business and Management, Vol. 16 No. 11, pp. 7-16.

Bryman, A. and Bell, E. (2011), Business Research Methods, 3rd ed., Oxford University Press, Oxford.

Caniato, F. and Größler, A. (2015), "The moderating effect of product complexity on new product development and supply chain management integration", Production Planning $\mathcal{E}$ Control, Vol. 26 No. 16, pp. 1306-1317, doi: 10.1080/ 09537287.2015 .1027318$.

Carrillo, J.E. and Franza, R.M. (2006), "Investing in product development and production capabilities: the crucial linkage between time-to-market and ramp-up time", European Fournal of Operational Research, Vol. 171 No. 2, pp. 536-556, doi: 10.1016/j.ejor.2004.08.040.

Chen, J., Reilly, R.R. and Lynn, G.S. (2005), "The impacts of speed-to-Market on new product success: the moderating effects of uncertainty", IEEE Transactions on Engineering Management, Vol. 52 No. 2, pp. 199-212, doi: 10.1109/ TEM.2005.844926.

Cooper, R.G. (2011), Winning at New Products: Creating Value through Innovation, 4th ed., Basic Books, New York, NY.

Cooper, R.G. (2019), "The drivers of success in new-product development”, Industrial Marketing Management, Vol. 76, pp. 36-47, doi: 10.1016/j.indmarman.2018.07.005.

Cooper, R.G., Edgett, S.J. and Kleinschmidt, E.J. (2004a), "Benchmarking best NPD practices - II", ResearchTechnology Management, Vol. 47 No. 3, pp. 50-59, doi: 10.1080/08956308.2004.11671630.

Cooper, R.G., Edgett, S.J. and Kleinschmidt, E.J. (2004b), "Benchmarking best NPD practices - III", ResearchTechnology Management, Vol. 47 No. 6, pp. 43-55, doi: 10.1080/08956308.2004.11671662.

Duriau, V., Reger, R. and Pfarrer, M. (2007), “A content analysis of the content analysis literature in organization studies: research themes, data sources, and methodological refinements", Organizational Research Methods, Vol. 10 No. 1, pp. 5-34, doi: 10.1177/1094428106289252.

Ellwood, P., Grimshaw, P. and Pandza, K. (2017), "Accelerating the innovation process: a systematic review and realist synthesis of the research literature", International fournal of Management Reviews, Vol. 19 No. 4, pp. 510-530, doi: $10.1111 /$ ijmr. 12108 .

Ernst, H., Hoyer, W.D. and Rübsaamen, C. (2010), "Sales, marketing, and research-and-development cooperation across new product development stages: implications for success", Fournal of Marketing, Vol. 74 No. 5, pp. 80-92, doi: 10.1509/jmkg.74.5.080.
Filippini, R., Salmaso, L. and Tessarolo, P. (2004), "Product development time performance: investigating the effect of interactions between drivers", fournal of Product Innovation Management, Vol. 21 No. 3, pp. 199-214, doi: 10.1111/ j.0737-6782.2004.00070.x.

Gordon, G.L., Schoenbachler, D.D., Kaminski, P.F. and Brouchous, K.A. (1997), "New product development: using the salesforce to identify opportunities", fournal of Business E Industrial Marketing, Vol. 12 No. 1, pp. 33-50, doi: 10.1108/08858629710157922.

Guenzi, P., Sajtos, L. and Troilo, G. (2016), "The dual mechanism of sales capabilities in influencing organizational performance", Fournal of Business Research, Vol. 69 No. 9, pp. 3707-3713, doi: 10.1016/j.jbusres.2016.03.033.

Haapasalo, H. and Kess, P. (2002), "Managing creativity - is it possible to control the birth of innovation in product design", International fournal of Technology Management, Vol. 24 No. 1, pp. 57-69, doi: 10.1504/IJTM.2002.003044.

Harmancioglu, N., McNally, R.C., Calantone, R.J. and Durmusoglu, S.S. (2007), "Your new product development (NPD) is only as good as your process: an exploratory analysis of new NPD process design and implementation", RED Management, Vol. 37 No. 5, pp. 399-424, doi: 10.1111/j.1467-9310.2007.00486.x.

Homburg, C., Alavi, S., Rajab, T. and Wieseke, J. (2017), "The contingent roles of $\mathrm{R} \& \mathrm{D}$-sales versus $\mathrm{R} \& \mathrm{D}$-marketing cooperation in new-product development of business-tobusiness firms", International fournal of Research in Marketing, Vol. 34 No. 1, pp. 212-230, doi: 10.1016/j. ijresmar.2016.05.008.

Isoherranen, V. and Majava, J. (2018), "Customer care excellence in the new product development process: a case study", International fournal of Value Chain Management, Vol. 9 No. 1, pp. 26-37, doi: 10.1504/ IJVCM.2018.10012215.

Jobber, D. and Lancaster, G. (2009), Selling and Sales Management, 8th ed., Pearson Education Limited, Harlow.

Kang, M., Lee, G., Hwang, D.W., Wei, J. and Huo, B. (2020), "Effects of cross-functional integration on NPD success: mediating roles of customer and supplier involvement", Total Quality Management \& Business Excellence, doi: 10.1080/ 14783363.2020.1736543.

Kess, P. and Haapasalo, H. (2002), "Knowledge creation through a review practice in software development project - a case from telecom industry", International fournal of Production Economics, Vol. 80 No. 1, pp. 49-55, doi: 10.1016/ S0925-5273(02)00242-6.

Kinnunen, T., Aapaoja, A. and Haapasalo, H. (2014), "Analysing internal stakeholders' salience in product development", Technology and Investment, Vol. 5 No. 2, pp. 106-115, doi: 10.4236/ti.2014.52011.

Kuester, S., Homburg, C. and Hess, S.C. (2012), "Externally directed and internally directed market launch management: the role of organizational factors in influencing new product success", Fournal of Product Innovation Management, Vol. 29 No. 1, pp. 38-52, doi: 10.1111/j.1540-5885.2012.00968.x.

La Rocca, A., Moscatelli, P., Perna, A. and Snehota, I. (2016), "Customer involvement in new product development in B2B: the role of sales", Industrial Marketing Management, Vol. 58, pp. 45-57, doi: 10.1016/j.indmarman.2016.05.014. 
Lahtinen, N., Mustonen, E. and Harkonen, J. (2019), "Commercial and technical productization for Fact-Based product portfolio management over lifecycle", IEEE Transactions on Engineering Management, Vol. 68 No. 6, doi: 10.1109/TEM.2019.2932974.

Lehto, J., Harkonen, J., Haapasalo, H., Belt, P., Mottonen, M. and Kuvaja, P. (2011), "Benefits of DfX in requirements engineering", Technology and Investment, Vol. 2 No. 1, pp. 27-37, doi: 10.4236/ti.2011.21004." No

Majava, J., Haapasalo, H., Belt, P. and Mottonen, M. (2013), "Product development drivers in literature and practice", International Fournal of Product Development, Vol. 18 No. 6, pp. 512-530, doi: 10.1504/IJPD.2013.058555.

Malshe, A. and Biemans, W. (2014), "The role of sales in NPD: an investigation of the U.S.Health-Care industry", Fournal of Product Innovation Management, Vol. 31 No. 4, pp. 664-679, doi: 10.1111/jpim.12159.

Moncrief, W.C. and Marshall, G.W. (2005), "The evolution of seven steps of selling", Industrial Marketing Management, Vol. 34 No. 1, pp. 13-22, doi: 10.1016/j. indmarman.2004.06.001.

Morgan, T., Anokhin, S., Song, C. and Chistyakova, N. (2019), "The role of customer participation in building new product development speed capabilities in turbulent environments", International Entrepreneurship and Management fournal, Vol. 15 No. 1, pp. 119-133, doi: 10.1007/s11365-018-0549-9.

Sundquist, V. and Melander, L. (2021), "Mobilizing resources in product development by organizational interfaces across firms, units and functions", fournal of Business $\mathcal{F}$ Industrial Marketing, Vol. 36 No. 2, pp. 307-323, doi: 10.1108/JBIM10-2019-0445.

Tatikonda, M.V. and Montoya-Weiss, M.M. (2001), "Integrating operations and marketing perspectives of product innovation: the influence of organizational process factors and capabilities on development performance", Management Science, Vol. 47 No. 1, pp. 152-172, doi: 10.1287/mnsc.47.1.151.10669.

Tih, S., Wong, K.-K., Lynn, G.S. and Reilly, R.R. (2016), "Prototyping, customer involvement, and speed of information dissemination in new product success", fournal of Business \& Industrial Marketing, Vol. 31 No. 4, pp. 437-448, doi: 10.1108/JBIM-09-2014-0182.

Tolonen, A., Haapasalo, H., Harkonen, J. and Verrollot, J. (2017), "Supply chain capability creation - the creation of the supply chain readiness for a new product during product development process", International fournal of Production Economics, Vol. 194, pp. 237-245, doi: 10.1016/j. ijpe.2017.09.007.

Tynan, C. and McKechnie, S. (2010), "Experience marketing: a review and reassessment", Fournal of Marketing Management, Vol. 25 Nos 5/6, pp. 501-517, doi: 10.1362/ $026725709 \mathrm{X} 461821$.

Ulrich, K.T. and Eppinger, S.T. (2008), Product Design and Development, 4th ed., International edition, McGraw-Hill, Boston.

Van Hoek, R. and Chapman, P. (2007), "How to move supply chain beyond cleaning up after new product development", Supply Chain Management: An International fournal, Vol. 12 No. 4, pp. 239-244, doi: 10.1108/13598540710759745.

Veldhuizen, E., Hultink, E.J. and Griffin, A. (2006), "Modeling market information processing in new product development: an empirical analysis", fournal of Engineering and Technology Management, Vol. 23 No. 4, pp. 353-373, doi: 10.1016/j.jengtecman.2006.08.005.

Verrollot, J., Tolonen, A., Harkonen, J. and Haapasalo, H. (2017), "Supply capability creation process: key milestone criteria and activities", fournal of Industrial Engineering and Management, Vol. 10 No. 3, pp. 495-521, doi: 10.3926/ jiem. 2375.

Vorhies, D.W. and Morgan, N.A. (2005), "Benchmarking marketing capabilities for sustainable competitive advantage", Fournal of Marketing, Vol. 69 No. 1, pp. 80-94, doi: 10.1509/jmkg.69.1.80.55505.

Yan, J., Zheng, Y., Bao, J., Lu, C., Jiang, Y., Yang, Z. and Feng, C. (2021), "How to improve new product performance through customer relationship management and product development management: evidence from China", fournal of Business E Industrial Marketing, Vol. 36 No. 1, pp. 31-47, doi: 10.1108/JBIM-05-2019-0190.

Zidane, Y.J.T., Klakegg, O.J., Andersen, B. and Hussein, B. (2018), "Superfast!' managing the urgent: case study of telecommunications infrastructure project in Algeria", International fournal of Managing Projects in Business, Vol. 11 No. 2, pp. 507-526, doi: 10.1108/IJMPB-12-2016-0101.

\section{Corresponding author}

Petteri Annunen can be contacted at: petteri.annunen@ oulu.fi 